\title{
Integrating Intellectual Property Rights and Development Policy in Agriculture, Biotechnology and Genetic Resources
}

\author{
Tandan Neeraj $^{2}$ and Yadav Seema ${ }^{1}$ \\ Department of Biotechnology, Singhania University, Rajasthan - 333515, India ${ }^{l}$ \\ Scientific and Applied Research Center, Meerut- 250001, India ${ }^{2}$
}

\begin{abstract}
This paper aims to provide a comprehensive background and overview of key issues, debates and positions related to the international regulation and application of intellectual property rights over agriculture, genetic resources, including biotechnology and the use of IPR's as plant and intellectual property protection. It explores the linkages among biological diversity, biotechnology developments and intellectual property with specific view on the relationship between access to biological and genetic resources, agriculture systems and increased poverty levels in India. This paper examines the significance of intellectual property rights in agricultural innovations, genetic resources and biotechnology and the possibilities for the protection through the context of the TRIPS and the WTO agreement on Aspects of Intellectual Property Rights. With the growth of private investment in developing country, agriculture, genetic resources, new advances in the biotechnology, and rapid integration of developing countries into the global trading system, intellectual property rights (IPRs) have become an important concern in the agricultural sector. The paper focuses specifically on the case of India and other developing countries, implementing IPRs in agriculture and Biotechnology. Findings indicate that yields grew significantly during the last two decades due to the combination of public investment in hybrid breeding programs that generated new materials offering substantial yield gains, and biological IPRs conferred by hybridization that conveniently need for substantial productivity growth in agriculture.
\end{abstract}

Key words: Intellectual property rights, Agricultural research and development, Biotechnology, Genetic resources, Plant protection, Farmer's right, India

\section{Introduction}

The importance of the agricultural sector in developing countries as a source of food, incomes, employment and often foreign exchange cannot be overstated. As much as good health, a productive and sustainable agricultural sector is critical to achieving economic growth and poverty reduction. About three quarters of the world's poor people live and work in rural areas (IFAD, 2001). The raising productivity in agriculture can directly stimulating overall economic growth of the country, increase the incomes and employment levels of the majority of poor people dependent on agriculture. It can also help to reduce food prices and increase food security for poor people in both rural and urban sectors.

In developing countries, technical progress traditionally occurred through a process of on-farm experimentation, selection and adaptation of traditional landraces of crops. This was supplemented by purposive breeding of new varieties of crops, mainly through crossing varieties with desirable characteristics. This process of research was largely conducted in the public sector by national research institutes, supported by a network of international research institutes, for the last thirty years under the Consultative Group on International Agricultural Research (CGIAR). It was this network which led to the Green Revolution of the 1960s, based initially on high yielding semi-dwarf varieties of rice and wheat. In spite of criticisms of its environmental and distributional impact, this technology is widely credited with having had a favourable impact on nutrition, employment and incomes, mainly in the areas of developing countries capable of reasonably assured irrigation. Subsequently, further breeding efforts have tried, but with less success, to extend these technologies to new crops and to rainfed and dryland areas.

More recently, significant changes have occurred in both the technology and the structure of research in agriculture. First, the advent of biotechnology, and in particular genetic engineering, in the last twenty years has vastly expanded the possibilities of what can be achieved in agricultural research (for example, introducing new genetic traits, hybrids through technology transfer in plants). Secondly, while public investment in public research, at least through the CGIAR, has tended to stagnate in recent years, investment by the private sector has gone up rapidly. Market forces have increasingly guided the direction and purpose of additional research spending.

\section{Intellectual Property Rights In Agriculture}

The vegetatively propagated plants were first made patentable in the US in 1930. And the protection of plant varieties (or plant breeder's rights - PBRs), a new form of intellectual property, only became widespread in the second half of the 20th Century. Thus systems for the protection of plants derive from the economic 
Integrating Intellectual Property Rights and Development Policy in Agriculture, Biotechnology and structure and circumstances of agriculture that prevailed in developed countries in this period. That such systems came into being reflected the growing interest of private breeders in protecting their intellectual property. Farmers have traditionally replanted, exchanged or sold seed from the 'previous years' crop which means that breeders have difficulty in recouping the investments made in improved varieties through repeat sales. Patents or PBRs normally impose restrictions on farmers ability to sell grown seed and thus enhance the market for the breeder's seed. In the developed countries, reuse of seeds remains quite common although for many crops annual purchase is now the rule and in developing countries the majority of farmers reuse, exchange or sell informally to neighbours, and annual purchase of new seed is relatively rare in most countries. Intellectual property protection can help promote research and innovation relevant to the needs of developing countries and poor people. With the adoption of the TRIPS Agreement, developing countries have been obliged to adopt protection of plant varieties, by patents or by other means, without any serious consideration being given to whether such protection would be beneficial, both to producers and consumers, or its possible impact on food security. TRIPs, has become more important than ever before at every stage of planning, research, upscaling and commercialisation of agricultural technologies.

There are seven forms of intellectual property rights recognised in the TRIPs Agreement. These include, Copyright and related rights, Trademarks, Geographical Indications, Industrial Designs, Patents, Layout-Designs (topographies) of integrated circuits, and protection of undisclosed information. This agreement also covers provisions related to control of anti-competitive practices in contractual licences, although, it does not directly relate to IPR. Various forms of IPR in different areas of agriculture is put to practice, we may face serious problems unless timely remedial measures are taken, awareness is brought out and also due emphasis is given on IPR literacy, higher education and capacity building in the country.

Establishment of the international institutional mechanisms, such as, the Convention on Biological Diversity (CBD) and the WTO, and further, signing of International Treaty on Plant Genetic Resources for Food and Agriculture (ITPGRFA), the growing importance and the global scope of IPR in agriculture are well realised and recognised. The IPR, after long debate, is recognised as an asset and means of rewarding and harvesting the fruit of agricultural research and development. Recognition of intellectual property rights provides an effective means of protecting and rewarding innovators. This acts as a catalyst in technological and economic development. The essence of regulation of IPR by law is to balance private and public interests. At the same time, equitable benefit sharing is, although, agreed upon under the CBD, is yet to be realised in effective terms.

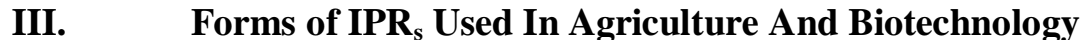

Legal mechanisms include patents, plant variety protection, trademarks, trade secrecy rights, and plant breeders' rights, among others. Biological mechanisms include hybridization and genetic use restriction technologies (GURTs). These legal and biological mechanisms are reviewed in the following paragraphs and summarized in Table.

\section{Legal IPR Mechanisms \\ Plant Patents}

Although patents are the most common form of IPRs in the manufacturing sector, most countries disallow patenting of plants for economic security reasons - for example, concerns that temporary market power may disrupt food supplies, food prices, or national food security. Despite this reasoning, the United States became the first country to specifically allow such patenting under the Plant Patent Act (PPA) of 1930.

The PPA specifically provides 20 -year patent protection for inventions derived from asexually (but non tuber propagated) reproduced varieties, implying that the patentable invention is an exact genetic replica of its parents (Fernandez-Cornejo 2004; Fuglie et al. 1996).

Plant patents under the PPA are issued for inventions that encompass the entire plant in question. Due to this aspect, infringement can occur only if the innovator can demonstrate that an imitator has derived a plant directly from the patented plant through asexual propagation. This means that an imitator who is able to propagate the patented plant independent of the patent owner's stock cannot be held accountable for infringement. In effect, this limits the importance of plant patents in the United States, and in other countries where they have been subsequently replicated.

\section{Plant Variety Protection}

Plant variety protection (PVP) is a patent-like system that allows an owner/innovator to prohibit specific unauthorized uses of his or her invention. European nations were the first countries to leverage PVPs as an incentive mechanism for agricultural innovation under the auspices of the International Convention for the Protection of New Varieties of Plants (UPOV, established in 1961 and revised in 1972, 1978, and 1991). The UPOV framework, when adapted into a national legal system, offers protection for plant "varieties" that are new, distinct, uniform, and stable. These rights extend not only to the variety and its propagating materials but also to "harvested materials, including entire plants or parts of plants". 
Whereas PVP legislation does grant exclusive rights to the owner/innovator, it also contains provisions that allow other innovators to use the protected materials for research purposes (called "breeders' rights") and farmers to save seed for planting in subsequent seasons (called "farmers' privilege").

Breeders' rights allow access to protected varieties for breeding and research purposes. Due to the sequential nature of plant breeding wherein the best attributes of existing varieties are combined to produce new varieties that express the best attributes of the parents, breeders' rights are considered critical to ensuring continuous cultivar improvement.

Farmers' privilege allows farmers' to re-use seeds of protected varieties. Under the UPOV 1978 Act, the scope of PVP does not include farm-saved seeds. However, under the UPOV 1991 revisions, farmers' privilege became a national option and a nation may allow farmers' privilege as an exception under certain circumstances. For example, in the European Union small-scale farmers do not pay royalty whereas large-scale farmers pay royalty (usually 50 percent of normal rate) for the re-use of seeds of protected varieties. In the United States, the revisions disallowed exchange of seeds between farmers, but farmers can re-use seeds for their own use.

According to the UPOV Act in 1991 aimed to strengthen breeder's rights and other disincentives implicit in the act's earlier version (Kolady and Lesser 2009). First, the scope of the breeders' rights was expanded to include the harvested material and also the products out of the harvested material at the expense of farmer's privilege. Second, the revisions introduced a distinction between initial varieties developed by breeders and "essentially derived" varieties that integrate only slight alterations in the initial variety and therefore cannot be sold without permission of the initial variety's owner/innovator. Third, the revisions allowed farmer's privilege as a national option, such that different countries could choose different levels of privilege for their farmers.

\section{Utility Patents}

Utility patents use as a protecting biological innovations in the United States with the U.S. Supreme Court Diamond v. Chakrabatry decision in 1980 that declared "anything under the sun which is made by man" to potentially be patentable subject matter. An applicant variety must be new (novel), be non obvious (similar to distinctness), have utility (a criteria not required for PVP), and be subjected to examination. The innovation for deposits with the competent authority are typically required and are made publicly available, although imitation is limited in sofar as breeder's rights and farmer's privilege do not apply to utility patents. Due to these factors, patent protection is viewed as providing notably stronger protection than PVP.

The role of utility patents in limiting the entry to plant breeding by restricting access to germplasm, Lesser (2009) proposes a two-tier system of protection for plants where plant breeding leads to annual incremental improvements interspersed by occasional major advancements. The study proposes using the existing PVP system as the lower level of protection (while requiring farmers to pay reasonable royalties) on saved seeds, and using utility patents based on functional non-obviousness standards as the higher level.

\section{Trademarks}

The aim of use of trademark is to denote the source or origin of a good or service, and implicitly provides the consumer with a warrant of the quality of the good or service bearing the mark. Legal protection is provided for trademarks through a system of registration. Both public research organizations and private enterprises can use trademarks to identify and protect their innovations. For example, seed companies can market their products under a brand name to create brand recognition among consumers, capture greater market share, distinguish their product from those of imitators, and bar the entry of imitators. However, while patents, PVPs, and utility patents are seen as intellectual property (IP) protection mechanisms that are essential to a firm's R\&D strategy, trademarks are more commonly viewed as part of a firm's marketing strategy (Louwaars et al. 2005).

\section{Trade Secrecy Laws}

Trade secrets, in contrast to the a forementioned legal mechanisms, are not a registered form of IP protection, and are of unlimited duration as long as the holder of the trade secret makes reasonable efforts to maintain the secrecy. It is simply apply where an innovator holds some information that is essential to his or her business and can demonstrate that he or she has made reasonable efforts to maintain its secrecy. Trade secrecy laws are applied most often in the case of hybrids, where the identification of the hybrid's parental lines is considered a trade secret belonging to the innovator (Moschini 2001). However, the parental lines kept as trade secrets may never become available to competitors and farmers, unlike the case of patents or PVP, where protection lasts only for a limited period.

Table. Forms of IPR $\mathrm{S}_{\mathrm{S}}$ used in Agriculture and Biotechnology

\begin{tabular}{|llll|}
\hline Form of IPR & Example & $\begin{array}{l}\text { Focus Crops/Products } \\
\text { Sexually propagated }\end{array}$ & $\begin{array}{l}\text { Year } \\
\text { (Country) } \\
\text { plants }\end{array}$ \\
$\begin{array}{llll}\text { Technology (hybrids) } \\
\text { Plant patents }\end{array}$ & $\begin{array}{l}\text { Hybrids } \\
\text { U.S. Plant Patent Act }\end{array}$ & Asexually propagated & 1930
\end{tabular}


Integrating Intellectual Property Rights and Development Policy in Agriculture, Biotechnology and

Plant variety

protection

Utility patents

Act

Trade secret law

Technology

Technology (GURT)

plants

Sexually propagated

plants $^{\mathrm{b}}$

Microorganisms

Plants

Animals

Parental lines of hybrids

Genetic modification

technology/crops

Source : Authors ; Fernandez-Cornejo (2004) ;Fuglie et al. (1996); Shi (2006).

Note : ${ }^{a}$ Hybrids of maize, sorghum, and wheat were developed in 1920,1952, and 1968 ,

respectively, ${ }^{\mathrm{b}} \mathrm{Hybrids}$ became eligible for protection in the United States in 1985.

\section{Biological IPR Mechanisms Hybridization}

Hybrids are the key form of biological IPR in agriculture. In this reference, hybridization prevents farmers from saving seed for their own use or selling the seed to their neighbors, a practice that farmers can do with self-or open-pollinated varieties as a matter of convention in many developing countries or under the protection of farmer's rights laws in other countries. Since farmers cannot produce their own hybrid seed without access to significant volumes of inbred parent seed, private firms provide significant value in the form of increased hybrid yields.

However, hybridization does not necessarily provide protection for developers of new hybrids from competitors who can access parent seed in various ways and then sell "look-alike" hybrids. To prevent this type of misallocation, seed companies require legal IP protection, adequate analytical techniques (for example, molecular markers) to trace the origins of imposters and counterfeits, and effective enforcement in the form of legal recourse for misallocated material. In United States, hybridized crops such as sorghum and maize, firms capture 35 to 48 percent of the gains from improved seeds and for nonhybrid crops such as wheat, soybean and cotton, firms' share of the yield gains are lower, on the order of 12 to 24 percent (Fuglie et al. 1996).

Genetic Use Restriction Technologies (GURTs)

A V-GURT, is a technology, renders the subsequent generation of seed sterile, thus preventing farmers from saving seed without remuneration to the innovator. Similarly, T-GURT restricts the use of a particular trait integrated into the seed such that expression of the trait can only be turned on by the external application of a (usually, chemical) inducer, thus requiring farmers to purchase the seedcum-inducer package from the innovator.

Still, none of these GURT technologies are in commercial application due to controversies over their potential impact on biodiversity, farmer's rights, industry competitiveness, and other concerns, and most companies have placed a moratorium on development (FAO 2001). However, were they to be commercialized, their application would open up an entirely new means of IPR protection without the time and territorial limitations associated with legal IPR mechanisms.

\section{IPR's As Applied To Genetic Resources}

The significance of IPRs, stated to genetic resources (GRs), including microorganisms, plants and animals are : patents, plant variety rights and trade secrets, although it should be noted that in the commercialisation of genetic resources, trademarks, and geographical indications, (GIs) may play an important role. Finally, in the conduct and representation of research conducted in relation to genetic resources, copyright and the protection of layout designs of integrated circuits, as well as patents and trade secrets may also play an important role.

\section{Plant genetic resources}

IPRs are a well-established institution in the agriculture sector, their application to agriculture is still developing. For example, plant breeders often find it difficult to prevent other breeders from imitating their work - for example, the improvement of an open -or self-pollinated crop variety such as maize, rice or wheat. They may also find it difficult to prevent farmers from saving grain from harvest and using that grain as seed in the subsequent season, without remunerating the breeder who provided the original variety improvements. This imperfect appropriability may reduce innovators' incentive to invest in the improvement of such crops. 
Animal genetic resources is also of relevance for other genetic resources for food and agriculture, such as aquatic genetic resources, invertebrate genetic resources, microorganism genetic resources and breeding methods.

The patenting of animals and genetic materials derived from animals has been highly controversial, resulting in many challenges. Article 27.2 of the TRIPS Agreement permits the exclusion from patentability inventions, the commercial exploitation of which "is necessary to protect morality". In some countries animals and their parts are eligible for patents, whereas in others the patenting of animals and animal materials is refused. In a third group of countries exceptions along the lines of Article 27.2 of the TRIPS Agreement are relied upon to refuse patents on animals in others the patenting of animals is subject to limitations. For example, Article 6.2(d) of the European Biotechnology Directive refuses patentability to "processes for modifying the genetic identity of animals which are likely to cause them suffering without any substantial medical benefit to man or animal, and also animals resulting from such processes.

Since the early 1990s the refusal of patentability to animal genetic material has been considered in inquiries in a number of countries (ASSCIST, 2001). In Canada, it was accepted that the "momentum of the biotech industry, the long history of patentability of gene sequences and the impact and complexity of existing international trade agreements make this, at present, an impractical and unrealistic option (T.A. Caulfield, et. al., 2003). The Australian Law Reform Commission pointed out that the exclusion of genetic materials from patentability may conflict with Article 27.1 of TRIPS which requires that patents shall be available for any inventions, and that patent rights shall be enjoyable without discrimination as to "the field of technology"(ALRC). In some countries, there has been a considerable growth in the patenting of animal cells and tissues (P. Oldham, 2004) for increasing production of meat, milk and other animal products.

Microorganisms

This reflects the majority decision of the US Supreme Court in Diamond v. Chakrabarty (U.S. 303, 310 (1980) that an engineered microorganism is patentable under the US Patent law (Bilski v. Kappos, 2010). Article 27.3(b) of the TRIPS Agreement provides for the patenting of microorganisms. However, as there is no definition of microorganism in the TRIPS Agreement, it is open to countries to permit the patenting of all kinds of microscopic biological materials, including cells and genes (M. Adcock and M. Llewelyn, 2000). For example the Indian Patents (Second Amendment) Act, 2002 provides for the patenting microorganisms including fungi, bacteria and viruses (R. B. Nair and P. C. Ramachandranna, 2010).

\section{Plants And Intellectual Property Protection}

The legal protection of genetic resources through IPRs or any other kind of law is the fact that scientific constructs do not sometimes lend themselves to legal categorisation. For example, the TRIPS Agreement in Article 27.3(b) provides that WTO Members may also exclude from patentability: "plants and animals other than micro-organisms, and essentially biological processes for the production of plants or animals other than non-biological and microbiological processes." The division between plants and animals on the one hand and micro-organisms on the other, is not as scientifically certain as the legal categories seem to suggest ( $\mathrm{M}$. Adcock, and M. Llewelyn, 2000). Additionally, a number of international organizations, with varying levels of scientific competence, are now concerning themselves with IPRs genetic and biological resources. Intellectual property protection can be conferred in relation to plant materials in a number of ways:

i. The US model of plant patents, which are distinct from normal (utility) patents

ii. Through allowing normal patents on plants or parts thereof, such as cells

iii. Through patenting plant varieties as is the practice in the US and in few other countries example, not in the $\mathrm{EU})$

iv. Through applying a sui generis form of plant variety protection (PVP), such as plant breeders' rights (as in the EU or the US) or other modalities

v. Through allowing patents on DNA sequences, and gene constructs including the gene, plants transformed with those constructs, the seed and progeny of those plants.

In addition, patents are widely used to protect the technologies which are employed in research on plant genomics.

\section{Plant Variety Protection (PVP)}

The protection of plant varieties is a mandatory obligation for signatories of the TRIPS Agreement is mandated by article 27.3(b). Countries are given the option of protecting plant varieties by patents or sui generis protection or by a combination of both, but since the commencement of the TRIPS Agreement in 1995, most countries tend to adopt the 1991 Act of the UPOV Convention, by way of compliance. Thus as of April 4, 2011, the UPOV Convention has 69 signatories, with 41 of those joining after 1 January, 1995. 13 Despite numerous commentaries and proposals for the adoption of alternative sui generis models, 14 only a few countries have 
Integrating Intellectual Property Rights and Development Policy in Agriculture, Biotechnology and adopted alternatives to UPOV. This is, in particular, the case of India, Malaysia and Thailand that have combined PVP with benefit sharing provisions inspired by the CBD.

\section{The UPOV Convention}

In plant variety rights legislation the plant breeder is conferred an exclusive right to do or to licence the following acts in relation to propagating material of the variety: (1) produce or reproduce the material; (2) condition the material for the purpose of propagation;

offer the material for sale; (3) sell the material; (4) import the material; (5) export the material; (6) stock the material for the purposes described above.

The protection under this legislation is afforded to a "breeder" or persons claiming through the breeder who is defined in Article 1 (iv) of the 1991 UPOV Act as the person who bred, or discovered or developed a variety". The general duration of plant variety rights under legislation based on the 1991 UPOV Act is 25 years in the case of trees and vines and 20 years for any other variety. During these periods the breeder or other licensee or owner of the right is entitled to exclusivity in its exploitation and commercialisation. Plant variety protection is established after a registration process.

\section{Farmers' Rights}

The ITPGRFA leaves it entirely up to national governments to implement Farmers' Rights. Thus, implementing specific Farmers' Rights is not an international obligation like that imposed under provisions in TRIPS. The rationale for Farmers' Rights combines arguments about equity and economics. Plant breeders and the world at large benefit from the conservation and development of plant genetic resources undertaken by farmers, but farmers are not recompensed for the economic value they have contributed. Farmers' Rights may be seen as a means of providing incentives for farmers to continue to provide services of conservation and maintenance of biodiversity.

The protection of plant varieties contains an inherent tendency to encourage uniformity and reduce biodiversity, to which the traditional practices of farmers are an essential counterweight. Farmers should be supported in recognition of the economic value they conserve, which is not recognised in the market system, and is to some extent threatened by technical change and the extension of plant breeders' protection. Moreover, the extension of intellectual property protection does carry the risk of restricting farmers' rights to reuse, exchange and sell seed, the very practices which form the basis of their traditional role in conservation and development.

Farmers' Rights are not an intellectual property right, but they need to be viewed as an important counter balance to the rights accorded to breeders in the formal sector under PVP or patents. However, implementing these rights at national level is complex. The Treaty provides for a financing mechanism to be set up, financed by contributions and the share of the proceeds of commercialisation, which will enable the implementation of agreed plans and programmes for farmers "who conserve and sustainably utilise plant genetic resources for food and agriculture (ITPGRFA Article 18.5).

\section{Conclusion}

The application and advantage of IPRs to Agriculture, Biotechnology and Genetic Resources has become a pronounced feature of agricultural innovation in the last few years. The FAO "Panel of Eminent Experts on Ethics in Food and Agriculture in 2005, has observed that "while most innovation for food and agriculture does not depend on IPRs, the acquisition and exercise of IPRs in this field raise a variety of ethical concerns". These include the fact that "IPRs protection may just mean the lack of access to innovations for the poor" and the concerns raised by the "patenting of merely isolated genes, the basic building blocks of life", which "are not invented, but are part of nature." Practically, the ability of individuals and corporations to obtain proprietary rights over agricultural innovations has important implications for food security (M. Blakeney, 2009). Generally, IPRs on Agriculture, Biotechnology and GRs may impede their use by third parties for further research and breeding during the term of protection, and thereby inhibit the development of new products and the capacity to address emerging problems, such as agricultural stresses caused by environmental and biological factors.

An important issue which has been discussed by the EPO and its appeal bodies over the last year is the question of the patentability of breeding methods. Had this patenting been permitted it might have rendered the PVP system largely redundant and it had been noted that the products of breeding remain patentable, with the consequential implications which that has for food security.

The practical effects of the application of IPRs to Agriculture, Biotechnology and GRs, is reflected in the strategy which are brought for infringements of IPRs. Till date, these strategy have mainly been brought against farmers who have cultivated patented GM crops without the permission of the relevant rights holder, as well as actions against importers of products containing patented GM ingredients. Potential IPR liability lies against governments, research institutes (international and national) and seed breeders who supply or utilise proprietary technologies. On 3rd December 2010, the TRIPS Agreement stated machinery to deal with the 
Integrating Intellectual Property Rights and Development Policy in Agriculture, Biotechnology and international trade in infringing goods and this machinery is currently being supplemented by the proposed Anticounterfeiting Trade Agreement (ACTA).

\section{Acknowledgement}

This paper was prepared through the contribution to the European Patent Office (EPO), Consultative Group on International Agricultural Research (CGIAR) and Food and Agriculture Organisation, United States, projects and was supported with generous funding, research articles from the International Treaty on Plant Genetic Resources (ITPGRFA) and Panel of Eminent Experts on Ethics in Food and Agriculture. The authors express their appreciation for the insights provided on this paper by literature study of recent research papers related to this paper. The authors express their high regards for the technical support provided by Dr. Neeraj Tandan, (Ph.D Guide), Secretary, Scientific and Applied Research Centre, Meerut, (U.P.). The authors also express their thanks for healthy support provided by the family for successfully completion of this paper.

\section{References}

[1]. Australia, Senate Standing Committee on Industry Science and Technology, Report on the Consideration of the Patent Bill, Canberra, AGPS, 1990; Canada, House of Commons Standing Committee on Health, Assisted Human Reproduction: Building Families, Ottawa, 2001; Ontario Ministry of Health and Long-Term Care, Genetics, Testing \& Gene Patenting: Charting New Territory in Healthcare: Report to the Provinces and Territories 2002; Australian Law Reform Commission, Genes and Ingenuity: Gene patenting and human health , ALRC Report 99, Canberra, AGPS, 2004.

[2]. $\quad$ ALRC, Genes and Ingenuity: Gene patenting and human health , at para. Vol. 7. pp.35.

[3]. Bilski v. Kappos, 130 S. Ct. 3218 (2010), This decision was referred to the recent Supreme Court decision as authority for the proposition that "laws of nature" are not patentable.

[4]. FAO (Food and Agriculture Organization). (2001). Potential impacts of genetic use restriction technologies (GURTs) on agricultural biodiversity and agricultural production systems. Rome: Food and Agricultural Organization.

[5]. Fernandez-Cornejo, J. (2004). The seed industry in U.S. agriculture: An exploration of data and information on crop seed markets, regulation, industry structure, and research and development. Agriculture Information Bulletin AIB 786. Washington, D.C.: U.S. Department of Agriculture Economic Research Service.

[6]. Foster, W. E., and R. Perrin. (1991). Economic incentives and plant breeding research. Faculty working paper. Raleigh, N.C., U.S.A.: North Carolina State University.

[7]. Fuglie, K., N. Ballenger, K. Day, C. Klotz, M. Ollinger, J. Reilly, U. Vasavada, and J. Yee. (1996). Agricultural research and development: Public and private investments under alternative markets and institutions. Agricultural Economics Report 735. Washington, D.C.: U.S. Department of Agriculture Economic Research Service.

[8]. IFAD (2001) "Rural Poverty Report (2001) - The challenge of ending rural poverty", IFAD, Rome, pp. 14-15. Source: http://www.ifad.org/poverty

[9]. ITPGRFA - Article 18.5

[10]. Kolady, D. E., and W. Lesser. (2009). But are they meritorious? Genetic productivity gains under plant intellectual property rights. Agricultural Economics 60 (1): 62-79.

[11]. Lesser, W. (2009). From penury to prodigal: Protection creep for U.S. plant varieties. Virginia Journal of Law \& Technology 14(4): $235-72$.

[12]. Louwaars, N., R. Tripp, D. Eaton, V. Henson-Apollonio, R. Hu, M. Mendoza, F. Muhhuku, S. Pal, and J. Wekundah.( 2005). Impacts of strengthened intellectual property rights regimes on the plant breeding industry in developing countries. Netherlands: Wageningen University.

[13]. M. Blakeney (2009). Intellectual Property Rights and Food Security, Wallingford, Oxford, Cab International

[14]. Moschini, G.(2001). Patents and other intellectual property rights. Staff general research paper. Ames, Iowa, U.S.A.: Iowa State University.

[15]. M. Adcock, and M. Llewelyn, (2000). Micro-organisms, Definitions and options under TRIPS. Quaker United Nations Office Programme, Occasional Paper 2.

[16]. M. Adcock and M. Llewelyn (2000). Micro-organisms, Definitions and Options under TRIPS and Micro-organisms, Definitions and Options under TRIPS: Supplementary Thoughts, QUNO, Occasional Paper 2, Geneva.

[17]. Panel of Eminent Experts on Ethics in Food and Agriculture (2005), 3rd Report, available at http://www.fao.org/docrep/010/a0697e/a0697e00.htm.

[18]. P. Oldham (2004)., A six-fold growth between 2000 and 2003 compared with 1990-2000 on Global Status and Trends in Intellectual Property Claims: Microorganisms, Submission to the Executive Secretary of the Convention on Biological Diversity.

[19]. R. B. Nair and P. C. Ramachandranna (2010). Patenting of microorganisms: Systems and concerns" 16 Journal of Commercial Biotechnology, 337-347.

[20]. T.A. Caulfield, B.M. Knoppers, E.R. Gold, L.E. Sheremeta and P.J. Bridge, (2003). Genetic technologies, health care policy, and the patent bargain"e 63 Clin Genet. 15-18 at 16. U.S. 303, 310 (1980). 